Jambura Fish Processing Journal Vol. 1 No. 2 Tahun 2019

DOI: https://doi.org/10.37905/ffpj.v1i2.5425 $\quad$ P-ISSN: 2655-3465 E-ISSN: -

\title{
ANALISIS MUTU IKAN LAYANG (Decapterus sp.) SEGAR SELAMA PENYIMPANAN MENGGUNAKAN LARUTAN EKSTRAK DAUN KELOR (Moringa oleifera) SEBAGAI PENGAWET ALAMI
}

\author{
Yusri Dj. Nai¹; Asri Silvana Naiu; Nikmawatisusanti Yusuf1 \\ 1 Jurusan Teknologi Hasil Perikanan, Fakultas Perikanan dan Ilmu Kelautan, Universitas Negeri Gorontalo, \\ J.Jenderal Sudirman No.06, Kota Gorontalo 96128, Gorontalo, Indonesia \\ Korespondensi: yusrinai@gmail.com \\ (Diterima 06-04-2020 / Dipublikasi 06-04-2020)
}

\begin{abstract}
ABSTRAK
Penelitian ini bertujuan untuk mengetahui pengaruh lama penyimpanan terhadap mutu ikan Layang (Decapterus sp.) segar yang direndam menggunakan larutan Ekstrak daun Kelor (Moringa oleifera). Perlakuan pada penelitian ini yaitu penggunaan larutan daun kelor $75 \%$ dengan lama penyimpanan 0,3 , 6, 9, 12, 15 dan 18 jam. Parameter yang diuji adalah karakteristik organoleptik melalui uji mutu hedonik yaitu kenampakan mata, insang, tekstur, daging, bau dan lendir, serta TPC dan pH. Analisis data yang digunakan untuk mutu hedonik adalah Kruskall wallis. Data analisis Kimia dan mikrobiologi menggunakan RAL (Anova). Hasil yang berpengaruh nyata dilanjutkan dengan uji Duncan. Hasil penelitian menunjukkan bahwa penggunaan larutan daun kelor 75\% mampu mempertahankan mutu ikan Layang (Decapterus sp.) segar hingga penyimpanan 12 jam dengan kriteria bola mata rata, kornea agak keruh, pupil agak keabuabuan; insang warna merah mudah atau coklat mudah dengan sedikit lendir agak keruh, lapisan lendir agak keruh, tekstur lunak, agak elastis bila ditekan dengan jari, bau segar, spesifik jenis kurang, dan sayatan daging sedikit kurang cemerlang,jaringan daging kuat. $\mathrm{pH}$ 6,24 dan nilai ALT yaitu 5,63 CFU/g, hasil yang diperoleh sesuai SNI 2729.2013 tentang mutu dan keamanan ikan segar.
\end{abstract}

Kata Kunci : Decapterus sp., kesegaran ikan, larutan daun kelor, mutu hedonik, pengawetan.

\begin{abstract}
This study aims to determine the effect of storage time on the quality of fresh flying (Decapterus sp.) Soaked using Moringa leaf extract solution. The treatment in this study was the use of $75 \%$ Moringa leaf solution with a storage time of $0,3,6,9,12,15$ and 18 hours. The parameters tested were organoleptic characteristics through hedonic quality tests namely eye appearance, gills, texture, meat, odor and mucus, as well as TPC and $\mathrm{pH}$. Analysis of the data used for hedonic quality is Kruskall wallis. Chemical and microbiological analysis data using RAL (Anova). Results that had a significant effect were followed by Duncan's test. The results showed that the use of $75 \%$ Moringa leaf solution was able to maintain the quality of fresh flying fish (Decapterus sp.) Up to 12 hours of storage with the criteria of flat eyeballs, cornea rather turbid, pupils rather grayish; gills red or easy brown with a little mucus rather turbid, mucous layer somewhat turbid, soft texture, somewhat elastic when pressed with fingers, fresh odor, specific type of less, and slightly less brilliant flesh incision, strong flesh tissue. $\mathrm{pH} 6.24$ and $\mathrm{ALT}$ value of $5.63 \mathrm{CFU} / \mathrm{g}$, the results obtained in accordance with SNI 2729.2013 regarding the quality and safety of fresh fish.
\end{abstract}

Keywords: Decapterus sp., freshness of fish, hedonic quality, moringa leaf solution, preservation.

http://ejurnal.ung.ac.id/index.php/jpj/issue/archive 


\section{PENDAHULUAN}

Ikan layang (Decapterus sp.) merupakan salah satu komunitas perikanan pelagis kecil yang penting di Indonesia. Ikan layang di perairan Indonesia terdapat lima jenis yang umum yakni $D$. kurroides, D. russelli, D. macrosoma, D. layang, dan D. macarellus (Hizaz, 2011).

Menurut data Dinas Kelautan dan Perikanan, Pertanian, dan Ketahanan Pangan Kota Gorontalo Tahun 2012, ikan layang yang diproduksi yaitu $3.266,9$ ton $(23,47 \%)$ dari total produksi seluruh ikan 13.741 ton di Kota Gorontalo dan pada tahun 2014 meningkat sebesar 24\%. Pada tahun 2018 potensi produksi mengalami peningkatan mencapai 5.226 ton. Hal ini menunjukkan bahwa ikan layang tersedia dalam jumlah banyak yang dapat dimanfaatkan (DKP Provinsi Gorontalo, 2018).

Menurut Nento (2013) ketersediaan ikan layang menduduki peringkat tertinggi dilihat dari segi penjualan, karena ikan ini dikonsumsi oleh hampir seluruh lapisan masyarakat. Kenyataan menunjukkan bahwa dari hasil tangkapan nelayan tradisional, penjualan ikan layang menempati jumlah lebih banyak dibanding penjualan ikan lainnya. Keberadaan Ikan layang ini penting dalam pemenuhan kebutahan gizi masyarakat karena mengandung protein $15-24 \%$, karbohidrat $1-3 \%$, lemak $0,1-22 \%$ dan air 60-84\% (Abdillah, 2006). Namun juga menjadi media yang cocok untuk kehidupan bakteri pembusuk. Oleh sebab itu, perlu adanya suatu upaya pengawetan untuk memperpanjang masa simpan ikan.
Menurut Mapiliandari et al., (2008) untuk memperpanjang daya simpan atau membuat ikan lebih awet maka perlu adanya suatu pengawetan pada ikan. Saat ini pengawetan yang sudah banyak dilakukan yaitu dengan menggunakan suhu rendah $0^{\circ} \mathrm{C}$ sampai $-5^{\circ} \mathrm{C}$ (Muljanto, 2000). Istilah pendinginan pada perikanan disebut chilling. Tujuan dari chilling adalah menghambat kegiatan mikroorganisme dan proses-proses lainnya yang terdapat pada ikan sehingga ikan tetap dalam kondisi segar. Cara termudah, praktis, dan tidak membutuhkan banyak biaya yang besar dalam penanganan ikan yaitu dengan menggunakan pendinginan es. Cara pendinginan sulit untuk diterapkan pada daerah yang tidak memilki pasokan listrik sehingga perlu mencari beberapa cara alternative yang dapat digunakan untuk mempertahankan mutu ikan segar yaitu dengan menggunakan tanaman yang memiliki bahan antimikroba. Salah satu tanaman yang memiliki senyawa aktif yang dapat digunakan untuk menjaga kemunduran mutu serta berpotensi untuk dijadikan sebagai pengawet alami yaitu daun tanaman kelor (Moringa oleifera).

Menurut Ayotunde et al, (2011) tanaman kelor merupakan salah satu jenis tanaman yang termasuk dalam famillia Moringaceae yang tumbuh di daerah tropis dan subtropis. Pada daun kelor terdapat kandungan zat kimia yaitu tannin, steroid, triterpenoid, flavonoid, saponin dan alkaloid (Kasolo et al., 2010) senyawa-senyawa tersebut yang dapat 
menghambat pertumbuhan bakteri pembusuk pada ikan. Berdasarkan hasil penelitian yang telah dilakukan Widowati, dkk. (2014) tentang uji aktifitas anti bakteri ekstrak daun kelor (Moringa oleifera) terhadap bakteri pembusuk ikan segar (Pseudomonas aeruginosa) menggunakan variasi konsentrasi $0 \%, 25 \%, 50 \%, 75 \%$ dan 100\% menunjukkan bahwa ekstrak daun kelor dengan konsentrasi $50 \%$ dapat digunakan sebagai anti bakteri (Pseudomonas aeruginosa) yaitu bakteri pembusuk pada ikan segar. Arizka (2017), telah meneliti ikan kakap merah dari jenis ikan demersal yang direndam selama 60 menit dalam larutan daun kelor dengan dosis $75 \%$ namun belum dapat menghambat bakteri pada ikan kakap $\left(2,37 \times 10^{6}\right.$ $\mathrm{CFU} / \mathrm{g})$.

Sehubungan dengan hasil penelitian pendahuluan maka penulis bermaksud untuk melakukan penelitian pada ikan layang (Ikan pelagis), menggunakan daun kelor sebagai pengawet alami didalamnya terdapat kandungan senyawa antibakteri yang bisa mempertahankan mutu ikan. Penelitian dilakukan untuk menguji kemampuan antibakteri daun kelor yang direndam selama 30 menit dan perlakuannya di uji selama penyimpanan berlangsung berapa lama hingga antibakteri yang terdapat pada daun kelor sudah tidak mampu mempertahankan mutu ikan layang. Penelitian pengawetan ikan layang menggunakan daun kelor belum pernah dilakukan. Oleh karena itu, penulis melakukan penelitian dengan judul
"Analisis Mutu Ikan Layang (Decapterus sp.) Segar Selama Penyimpanan Menggunakan Larutan Ekstrak Daun Kelor (Moringa oleifera) Sebagai Pengawet Alami".

\section{METODE PENELITIAN}

\section{Waktu dan Tempat Penelitian}

Penelitian ini dilaksanakan pada Januari sampai Agustsu 2018. Pengujian kimia dilakukan di Laboratorium Kesehatan Masyarakat Fakultas Kesehatan dan Keolahragaan Universitas Negeri Gorontalo. Pengujian organoleptik bertempat di Laboratorium Bioteknologi dan Karakterisasi Hasil Perikanan Jurusan Teknologi Hasil Perikanan Fakultas Perikanan dan IImu Kelautan Universitas Negeri Gorontalo.

\section{Alat dan Bahan}

Alat yang digunakan pada penelitian antara lain coolbox sebagai wadah penyimpanan, score sheet organoleptik, mesin penggiling atau blender, timbangan, timbangan digital, pisau, talenan, piring, magnetic stirrer, hot plate, autoclave, cawan, incubator, oven, mikropipet, label, loyang, tabung erlenmeyer, gelas beker, tabung reaksi, Thermolyne, freezer, waterbath, kertas cap, alumenium foil, Laminary air flow, kapas.

Bahan baku ikan layang yang dijadikan sampel pada penelitian ini berasal dari Tempat Pelelangan Ikan (TPI) Kota Gorontalo dan daun kelor yang diperoleh dari pohon kelor di Kecamatan Tamalate, Kota Goorntalo. Bahan yang digunakan 
untuk uji ALT bahan yang digunakan adalah sampel ikan layang segar, Media NA (Natrium Agar), aquades, Buffered pepton Water (BPW $0,1 \%$ ), asam perklorat, $\mathrm{NaOH}$, fenolftalein, silicon anti foaming.

\section{Prosedur Penelitian}

Penelitian ini dilakukan dua tahap yaitu penelitian pendahuluan dan utama. Penelitian pendahuluan bertujuan menentukan konsentrasi daun kelor yang akan digunakan pada penelitian utama. Penelitian utama bertujuan mengetahui efektivitas daun kelor terhadap mutu ikan layang segar selama penyimpanan.

\section{Penelitian Pendahuluan}

Penelitian pendahuluan didasarkan pada penelitian Ariska (2017), ikan kakap merah yang direndam selama 30 dan 60 menit dalam perendaman larutan daun kelor dengan konsentrasi berbeda $(25 \%, 50 \%$ dan $75 \%)$ dalam $100 \mathrm{ml}$ air yang membuktikan bahwa jumlah bakteri pada ikan kakap masih diambang batas (SNI ikan segar). Pembuatan konsentrasi larutan dalam penelitian ini berdasarkan penelitian sebelumnya yaitu waktu perendaman 30 dan 60 menit, dengan konsentrasi yang sama $(25 \%$, 50\% dan $75 \%)$ Namun dalam penggunaan air yang berbeda yaitu $1000 \mathrm{ml}$ air Pembuatan Konsentrasi larutan terlebih dahulu menyediakan stok larutan dengan perbandingan $1: 1$.

\section{Penelitian Utama}

Berdasarkan hasil penelitian pendahuluan maka dalam penelitian utama konsentrasi larutan daun kelor yang digunakan yaitu 75\% (750 larutan filtrat $+250 \mathrm{ml}$ aquades) dengan perendaman selama 30 menit dengan perlakuan penelitian yaitu lama penyimpanan 0 jam, 3 jam, 6 jam, 9 jam, 12 jam, 15 jam dan 18 jam.

Sampel ikan layang dibeli dari tempat pelelangan ikan (TPI) Kota Gorontalo dengan berat ikan per ekor berkisar $\pm 150 \mathrm{~g}$, berat pada setiap perlakuan $\pm 450 \mathrm{~g}$ (3 ekor ikan) dengan total untuk keseluruhan ikan yang digunakan pada semua perlakuan sebanyak $4 \mathrm{~kg}$, kemudian sampel dijaga kesegarannya dalam box sterofoam dengan es sebelum digunakan. Daun kelor diambil dari Kecamatan Kota Timur Kota Gorontalo. Pembuatan stok ekstrak air daun kelor diawali dengan pembuatan stok untuk semua perlakuan, membutuhkan daun kelor yang digunakan sebanyak $4500 \mathrm{~g}$ daun kelor dan aquades sebanyak $4500 \mathrm{ml}$. Daun kelor terlebih dahulu dibersihkan (dicuci) lalu diblender dengan (perbandingan $1: 1$ ) hingga halus kemudian disaring dan hasil filtratnya diambil untuk dijadikan stok larutan. Setelah stok didapatkan, Masing - masing perlakuan menggunakan 750 larutan filtrate $+250 \mathrm{ml}$ aquades. 


\section{HASIL DAN PEMBAHASAN}

\section{Analisis Nilai Total Plate Count (TPC) Ikan Layang (Decapterus sp.)}

Hasil pengujian mikrobiologi (Total Plate Count) ikan layang segar selama penyimpanan 0 jam, 3 jam, 6 jam, 9 jam, 12 jam, 15 jam dan 18 jam dengan larutan ekstrak daun kelor $75 \%$ dapat dilihat pada Gambar 1.

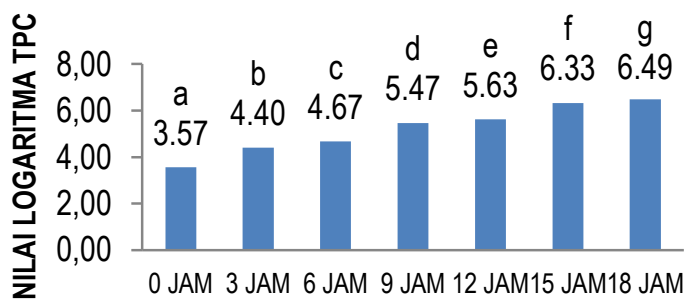

LAMA PENYIMPANAN

Gambar 1. Histogram nilai TPC ikan layang pada lama penyimpanan yang berbeda.

Histogram Gambar 1 menunjukkan nilai TPC ikan layang berada pada interval 3,57 CFU/g - 6,49 CFU/g. Nilai terendah terdapat pada perlakuan lama penyimpanan 0 jam (kontrol) dan nilai tertinggi terdapat pada perlakuan 18 jam

Berdasarkan uji Anova perlakuan lama penyimpanan berpengaruh nyata terhadap nilai TPC yang dihasilkan. Hasil uji Duncan menunjukkan bahwa semua taraf lama penyimpanan berbeda nyata.

Berdasarkan hasil penelitian penggunaan larutan ekstrak daun kelor konsentrasi 75\% hanya bisa mempertahankan mutu ikan layang selama 12 jam, karena pada lama penyimpanan tesebut jumlah TPC masih memenuhi standar berdasarkan SNI 01-2729.1-2006 syarat mutu ikan segar, yaitu http://ejurnal.ung.ac.id/index.php/jfpj/issue/archive
5.63 CFU/g masi memenuhi pada standar SNI mutu ikan segar selama penyimpanan berlangsung.

Kemunduran mutu terus terjadi, dilihat dari hasil pengamatan yang menunjukan bahwa, terjadi kenaikan jumlah bakteri pada setiap interval waktu penyimpanan yang hanya berselang selama 3 jam mengalami peningkatan. Hal ini diduga disebabkan oleh senyawa antibakteri seperti flavonoid, saponin dan tannin yang ada pada daun kelor jika disesuaikan dengan sifatnya, hanya bersifat sebagai bakteriostatik (menghambat laju pertumbuhan), bukan bersifat bakterisida (menghentikan laju pertumuhan/membunuh mikroba). Sehingga larutan ekstrak daun kelor tidak dapat lagi mempertahankan mutu pada lama waktu penyimpanan 15 sampai 18 jam yang menyebabkan mikroorganisme pembusuk terus berkembang biak.

Menurut Ruchmana (2017) bahwa kurangnya efektifitas daya hambat senyawa antimikroba disebabkan oleh perubahan kimia pada zat aktif selama penyimpanan, terutama senyawa polifenol seperti tannin dan flavonoid yang rusak selama proses oksidasi karena oksigen yang menyebabkan senyawa polifenol tersebut berubah struktur dan akhirnya menyebabkan kemampuannya sebagai antibakteri menurun. salah satu perubahan struktur senyawa zat aktif yang rusak karena oksidasi dapat dicontohkan dalam senyawa flavonoid. Flavonoid telah dikenal 
luas memiliki aktifitas sebagai senyawa antioksidan, antimelagonesis dan antimikroa yang berpotensi (Sulistyo dan Soeka, 1999). Akan tetapi flavonoid umumnya memiliki kelarutan yang rendah serta tidak stabil terhadap pengaruh cahaya, oksidasi dan peruahan kimia. Karena itu, apaila teroksidasi, strukturnya akan berubah dan fungsinya sebagai bahan aktif akan berkurang bahkan hilang (Kitao dan Sekine,1993).

\section{Hasil Analisis Organoleptik Mutu Ikan Layang (Decapterus sp.)}

Kenampakan Mata Ikan Layang (Decapterus sp.)

Mata merupakan indikator kesegaran utama yang dilihat oleh konsumen saat membeli ikan segar. Histogram nilai rata-rata mutu hedonik mata ikan layang selama penyimpanan 18 jam dapat dilhat pada Gambar 2.

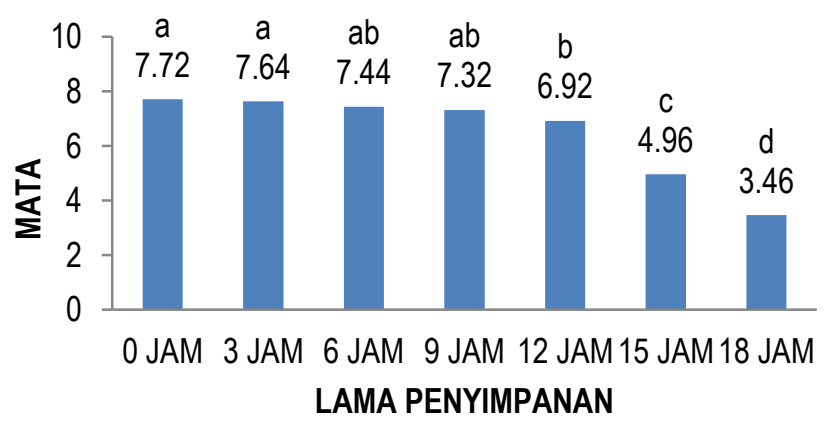

Gambar 2. Histogram nilai rata-rata mutu hedonik mata ikan layang pada lama penyimpanan yang berbeda.

Gambar 2 menunjukkan bahwa nilai mutu hedonik mata ikan layang dengan perlakuan larutan ekstak daun kelor konsentrasi 75\% selama penyimpanan semakin menurun. Mengacu pada standar mutu ikan segar yang ditetapkan oleh SNI
(2729-2013) bahwa nilai mutu hedonik mata ikan layang hasil perlakuan dengan lama penyimpanan hingga 12 jam masih memenuhi syarat nilai organoleptik yakni 6,92 (mendekati nilai Netral 7) dengan kriteria bola mata rata, kornea agak keruh, pupil agak keabu-abuan, agak mengkilap, spesifik jenis ikan. seiring dengan makin lama penyimpanan. Nilai mutu hedonik terendah pada perlakuan penyimpanan 18 jam yaitu 3,46 dengan kriteria bola mata cekung, kornea keruh, pupil keabu-abuan, tidak mengkilap. Nilai mutu tertinggi terdapat pada penyimpanan 0 jam yaitu 7,72 dengan kriteria bola mata rata, kornea dan pupil jernih, agak mengkilap spesifik jenis ikan.

Berdasarkan uji Kruskall wallis perlakuan lama penyimpanan yang berbeda berpengaruh nyata terhadap kenampakan mata yang dihasilkan. Hasil uji Duncan menunjukkan bahwa lama penyimpanan 0 hingga 9 jam tidak berbeda nyata demikian pula dengan pegujian 6 hingga 12 jam, tetapi berbeda nyata dengan lama penyimpanan 15 jam dan 18 jam.

Berdasarkan hasil penelitian bahwa rendahnya nilai mutu organoleptik kenampakan mata ikan layang dapat disebabkan oleh lama waktu penyimpanan. Sesuai dengan hasil pengamatan mata ikan layang mulai terlihat keruh, bola mata rata dan pupil agak keabu - abuan. Hal ini disebabkan karena setelah ikan mati, sistem kekebalan tubuh yang menjaga ikan dari serangan bakteri tidak bekerja lagi dan bakteri mulai masuk 
ke tubuh ikan. Bakteri-bakteri pembusuk pada ikan berasal dari luar tubuh ikan yang masuk melalui kulit atau dari dalam tubuh ikan itu sendiri.

Perubahan organoleptik mata ikan layang disebabkan adanya pertumbuhan bakteri pembusuk yang merubah membran sel. Hal ini sesuai dengan Agati, dkk (2007) dalam Herawati (2011) bahwa permeabilitas membran sel pada mata ikan terganggu akibat adanya senyawa fenol pada daun kelor sehingga menyebabkan kenampakan mata pada ikan mengalami perubahan. Menurut Ruchmana (2017) kurangnya efektifitas daya hambat senyawa antimikroba disebabkan oleh perubahan kimia pada zat aktif selama penyimpanan, terutama senyawa polifenol seperti tannin dan flavonoid yang rusak selama proses oksidasi karena oksigen. Hal ini sesuai pula dengan penelitian yang dilakukan oleh Ibrahim (2017) menunjukkan semakin lama waktu penyimpanan pada semua taraf konsentrasi larutan kemangi, kenampakan mata akan semakin menurun. Lamanya penyimpanan dengan penggunaan konsentrasi larutan daun kelor tidak dapat menghambat aktivitas mikroba sehingga tidak dapat mempertahankan nilai kenampakan mata karena disebabkan oleh aktivitas anti mikroba yang terdapat pada larutan daun kelor sudah tidak efektif.

\section{Insang Ikan Layang (Decapterus sp.)}

Histogram nilai rata-rata mutu hedonik insang ikan layang selama penyimpanan 18 jam dapat dilhat pada Gambar 3.

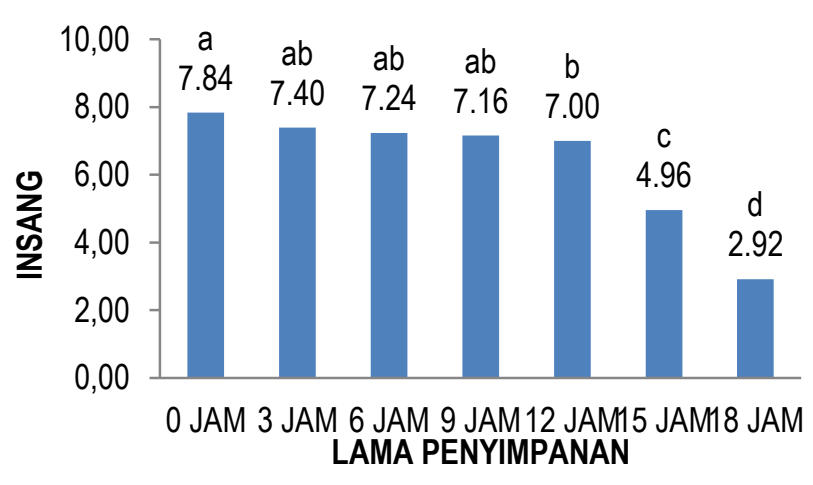

Gambar 3. Histogram nilai rata-rata mutu hedonik insang ikan layang lama penyimpanan yang berbeda.

Gambar 3 menunjukkan bahwa nilai mutu hedonik insang ikan layang hasil perlakuan pada penyimpanan 15 - 18 jam semakin menurun seiring dengan makin lamanya penyimpanan. Nilai mutu hedonik ingsan ikan layang yang terbaik hanya sampai pada lama penyimpanan 12 jam yaitu 7.00 dengan kriteria warna insang merah muda atau coklat muda dengan sedikit lendir agak keruh.

Mengacu pada standar mutu ikan segar yang ditetapkan oleh BSN (2013) bahwa insang ikan layang hasil perlakuan dengan lama penyimpanan 0 jam sampai 12 jam memenuhi syarat nilai organoleptik yakni 7 , sedangkan pada perlakuan penyimpanan 15 jam dan 18 jam belum memenuhi persyaratan SNI.

Berdasarkan uji Kruskall wallis perlakuan lama penyimpanan yang berbeda berpengaruh nyata terhadap kenampakan insang yang 
dihasilkan. Hasil uji Duncan menunjukkan bahwa lama penyimpanan 15 jam dan 18 jam berbeda nyata, tetapi tidak berbeda nyata dengan lama penyimpanan 0 hingga 9 jam, demikian pula dengan penyimpanan 3 hingga 12 jam.

Berdasarkan hasil penelitian menunjukkan bahwa semakin lama penyimpanan nilai organoleptik kenampakan insang ikan layang semakin menurun. Penurunan mutu yang cepat pada insang tidak terlepas dari kinerja insang memfilter oksigen dalam air saat respirasi sehingga insang menjadi tempat terakumulasinya mikroba (Fujaya, 2004). Penurunan nilai kenampakan insang berkaitan erat dengan jumlah bakteri pada ikan layang yang semakin meningkat selama penyimpanan yang diduga disebabkan oleh menurunnya efektifitas senyawa antimikroba pada larutan daun kelor. Keadaan tersebut dapat dijelaskan dengan terjadinya reaksi difusi (kesetimbangan) pada larutan daun kelor selama perendaman yang mengalami perubahan kepekatan akibat masuknya sebagian besar larutan pada tubuh ikan layang, dan akan keluar lagi pada saat penyimpanan waktu mencapai kesetimbangan antara larutan daun kelor yang berada didalam dan diluar tubuh ikan. akibatnya kemampuan daya hambat dari larutan ekstak daun kelor semakin berkurang yang menyebabkan pertumbuhan mikroorganisme bakteri pembusuk semakin bertambah dan berkembang.

http://ejurnal.ung.ac.id/index.php/jfpj/issue/archive

\section{Lendir Ikan Layang (Decapterus sp.)}

Histogram nilai rata-rata mutu hedonik lendir layang selama penyimpanan 18 jam dapat dilhat pada Gambar 4.

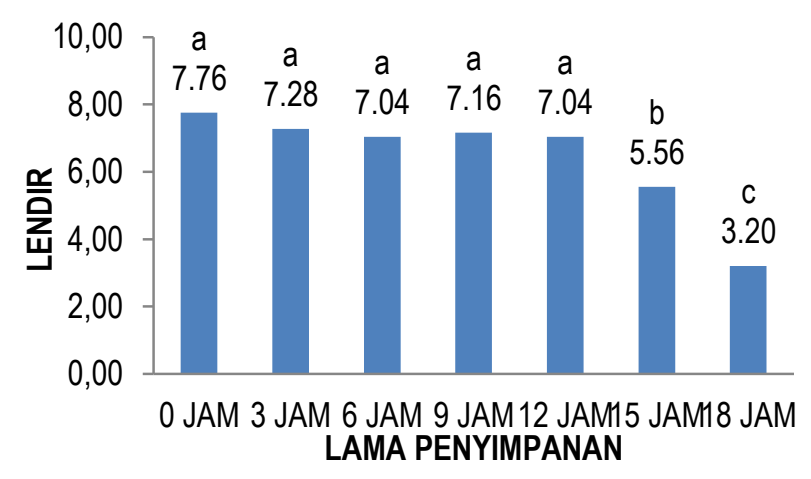

Gambar 4. Histogram nilai rata-rata mutu hedonik lendir ikan layang pada lama penyimpanan yang berbeda.

Gambar 4 menunjukkan nilai mutu hedonik lendir ikan layang hasil perlakuan semakin menurun seiring dengan makin lama penyimpanan. Nilai mutu hedonik terendah pada perlakuan penyimpanan 18 jam yaitu 3,20 yang dibulatkan 3 dengan kriteria lendir tebal sedikit menggumpal berubah warna. Mutu hedonik lender ikan layang yang dapat digolongkan pada kriteria ikan segar terdapat pada penyimpanan 0 hingga 12 yaitu 7,76 hingga 7.04 dengan kriteria lapisan lendir jernih, transparan cukup cerah sedangkan penyimpanan 15 jam nilai mutu hedonik berada dibawah standar yang ditetapkan SNI, yaitu 5,56 ( $<7)$.

Berdasarkan uji Kruskall wallis perlakuan lama penyimpanan yang berbeda berpengaruh nyata terhadap kenampakan lendir yang dihasilkan. Hasil uji Duncan menunjukkan bahwa lama penyimpanan 0 jam, 3 jam, 6 jam, 9 jam dan 12 
jam tidak bereda nyata, tetapi berbeda nyata dengan penyimpanan $15 \mathrm{jam}$ dan $18 \mathrm{jam}$.

Berdasarkan hasil penelitian bahwa semakin lama penyimpanan nilai mutu hedonik lendir ikan layang semakin menurun, hal ini berkaitan dengan adanya aktivitas bakteri yang memanfaatkan lendir ikan. Berdasarkan DKP (2008), mikroba banyak ditemukan di permukaan luar tubuh ikan (kulit dan insang) dan usus ikan segar. Menurut Djojosentono (1982) salah satu perubahan setelah ikan mati yaitu lendir terlepas dari kelenjar-kelenjar yang ada di dalam kulit, membentuk lapisan bening yang tebal disekeliling tubuh ikan. Lendir itu terdiri dari gluco protein dan menjadi substrat yang baik bagi pertumbuhan bakteri. Keberadaan larutan ekstak daun kelor sebagai antibakteri hanya mampu mempertahankan mutu lendir hingga 12 jam, karena penyimpanan yang semakin lama menyebabkan antibakteri pada larutan ekstrak daun kelor tidak efektif lagi.

\section{Daging lkan Layang (Decapterus sp.)}

Histogram nilai rata-rata mutu hedonik daging ikan layang selama penyimpanan 18 jam dapat dilhat pada Gambar 5 .

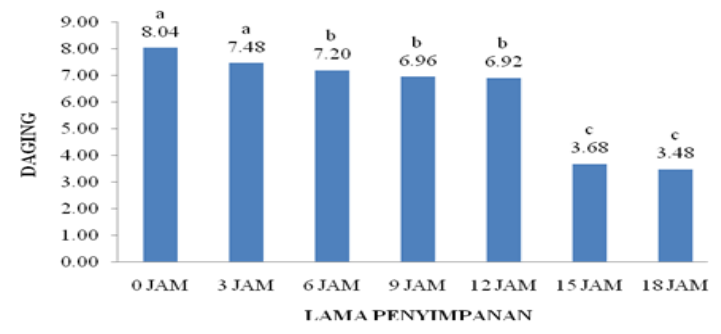

http://ejurnal.ung.ac.id/index.php/jfpj/issue/archive
Gambar 5. Histogram nilai rata-rata mutu hedonik daging ikan layang pada lama penyimpanan yang berbeda.

Gambar 5 menunjukkan nilai mutu hedonik daging ikan layang hasil perlakuan yang semakin menurun seiring dengan makin lamanya penyimpanan. Nilai mutu hedonik terendah pada perlakuan penyimpanan 18 jam yaitu 3,48 yang dibulatkan 4 dengan kriteria sayatan daging kusam, jaringan daging kurang kuat. Nilai mutu tertinggi terdapat pada penyimpanan 0 jam jam yaitu 8,04 yang dibulatkan 8 dengan kriteria sayatan daging cemerlang spesifik jenis, jaringan daging kuat.

Mengacu pada standar mutu ikan segar yang ditetapkan oleh SNI (2729-2013) bahwa daging ikan layang hasil perlakuan dengan lama penyimpanan 0 jam sampai 12 jam memenuhi syarat nilai organoleptik yakni 7 , sedangkan pada perlakuan penyimpanan 15 jam dan 18 jam belum memenuhi persyaratan SNI.

Berdasarkan uji Kruskal wallis perlakuan lama penyimpanan yang berbeda berpengaruh nyata terhadap daging yang dihasilkan. Hasil uji Duncan menunjukkan bahwa lama penyimpanan 0 hingga 3 jam tidak berbeda nyata, demikian pula 6 hingga 12 jam tetapi berbeda nyata dengan lama penyimpanan 15 hingga 18 jam.

Berdasarkan hasil penelitian perlakuan penyimpanan 0 dengan 3 jam tidak berbeda nyata, demikian pula dengan lama penyimpanan 3 jam hingga 12 jam memperlihatkan mutu daging ikan layang masih memenuhi syarat. Hal ini diduga 
karena senyawa antibakteri dalam larutan ekstrak daun kelor masih efektif dalam menghambat pertumbuhan bakteri, sehingga kerusakan dalam daging masih dapat dicegah. Menurut Benkeblia (2004) flavonoid memiliki aktivitas antibakteri yang berkerja dengan mekanisme menghambat pembentukan membran sel bakteri sehingga membran atau dinding sel tidak terbentuk atau terbentuk tidak sempurna. Membran sel mempunyai fungsi diantaranya mengendalikan masuk keluarnya berbagai zat dan merupakan lokasi sistem transport zat aktif, untuk itu terjadinya penghambatan bakteri dapat disebabkan karena kerusakan yang terjadi pada komponen structural membran sel bakteri.

\section{Bau Ikan Layang (Decapterus sp.)}

Histogram nilai rata-rata mutu hedonik bau ikan layang selama penyimpanan 18 jam dapat dilhat pada Gambar 6.

Gambar 6 menunjukkan nilai mutu hedonik bau ikan layang hasil perlakuan yang semakin menurun seiring dengan makin lamanya penyimpanan dengan konsentrasi daun kelor $75 \%$.

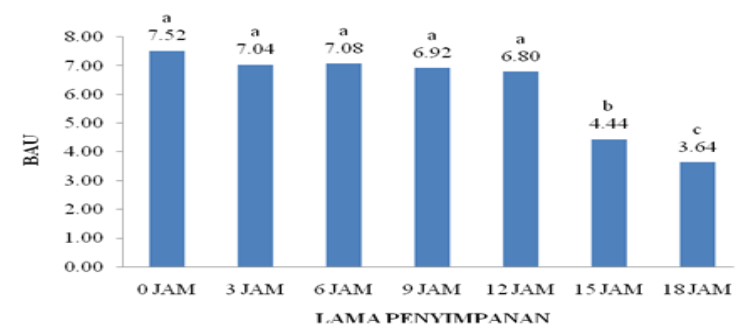

Gambar 6. Histogram nilai rata-rata mutu hedonik bau ikan layang pada lama penyimpanan yang berbeda.
Nilai mutu hedonik terendah pada perlakuan penyimpanan 18 jam yaitu 3,64 yang dibulatkan 4 dengan kriteria bau asam kuat. Nilai mutu tertinggi terdapat pada penyimpanan 0 jam yaitu 7,52 yang dibulatkan 7 dengan kriteria sama yaitu segar, spesifik jenis kurang.

Mengacu pada standar mutu ikan segar yang ditetapkan oleh SNI (2729-2013) bahwa bau ikan layang hasil perlakuan dengan lama penyimpanan 15 jam dan 18 jam tidak memenuhi syarat nilai organoleptik yakni 7. Sebab bau yang dominan yaitu daun kelor dibandingkan bau pada ikan layang.

Berdasarkan uji Kruskal wallis perlakuan lama penyimpanan yang berbeda berpengaruh nyata terhadap bau yang dihasilkan. Hasil uji Duncan menunjukkan bahwa lama penyimpanan 15 jam dan 18 jam berbeda nyata, sedangkan penyimpanan 0 jam, 3 jam, 6 jam, 9 jam hingga 12 jam tidak bereda nyata.

Hasil penelitian menunjukkan terjadi penurunan nilai organoleptik bau seiring dengan lama penyimpanan, hal ini berkaitan erat dengan aktivitas bakteri pada ikan layang serta daun kelor yang digunakan. Larutan ekstrak daun kelor memberikan bau yang nyata pada ikan, hal ini disebabkan karena senyawa minyak atsiri pada daun kelor termasuk golongan senyawa yang volatile seperti golongan monoterpen dan sesquiterpen yang termasuk golongan senyawa 
bersifat antimikroba yang mudah menguap Dewi, dkk ( 2013).

Penurunan mutu organoleptik bau ikan layang seiring dengan penurunan mutu mikrobiologis yaitu berdasarkan jumlah bakteri TPC. Hasil analisis organoleptik bau ikan maupun hasil pengujian TPC ikan menunjukkan hasil yang saling berkaitan. Semakin tinggi jumlah bakteri pada ikan layang jika dilihat pada pengujian TPC penyimpanan 18 jam 6,49 CPU/g semakin rendah nilai organoleptik bau pada penyimpanan 18 jam 3.64 begitu pula sebaliknya. Hal ini disebabkan karena bau yang timbul dari ikan, merupakan bau yang timbul akibat kerusakan komponen-komponen enzim dan aktifitas kimiawi pada ikan. Kerusakan tersebut disebabkan oleh aktivitas dan perombakan yang dilakukan bakteri.

\section{Tekstur lkan Layang (Decapterus sp.)}

Histogram nilai rata-rata mutu hedonik tekstur ikan layang selama penyimpanan 18 jam dapat dilhat pada Gambar 7.

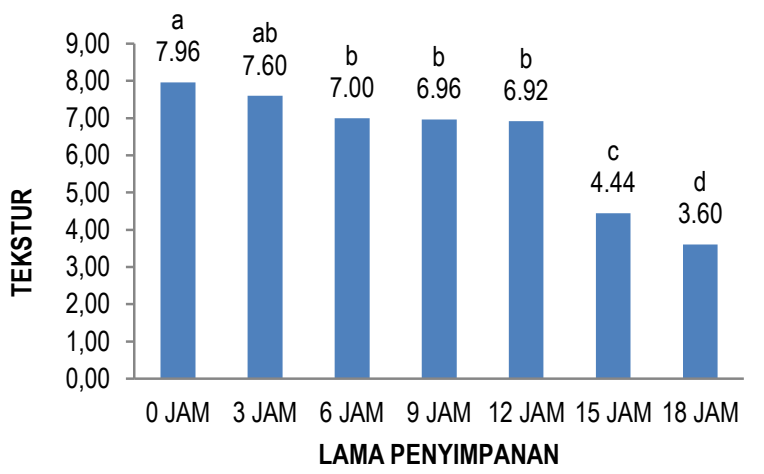

Gambar 7. Histogram nilai rata-rata mutu hedonik tekstur ikan layang pada lama penyimpanan yang berbeda.
Gambar 7 menunjukkan nilai mutu hedonik tekstur ikan layang hasil perlakuan yang semakin menurun seiring dengan makin lamanya penyimpanan dengan konsentrasi daun kelor $75 \%$. Nilai mutu hedonik terendah pada perlakuan penyimpanan 18 jam yaitu 3,60 (dibulatkan 4) dengan kriteria lunak bekas jari terlihat dan sangat lambat hilang. Nilai mutu tertinggi terdapat pada penyimpanan 0 jam yaitu 7,97 yang dibulatkan 8 dengan kriteria padat, kompak, elastis.

Mengacu pada standar mutu ikan segar yang ditetapkan oleh SNI (2729-2013) bahwa tekstur ikan layang hasil perlakuan dengan lama penyimpanan 0 jam sampai 12 jam memenuhi syarat nilai organoleptik yakni 7 , sedangkan pada perlakuan penyimpanan 15 jam dan 18 jam belum memenuhi persyaratan SNI.

\section{Berdasarkan uji Kruskal wallis perlakuan} lama penyimpanan yang berbeda berpengaruh nyata terhadap tekstur yang dihasilkan. Hasil uji Duncan menunjukkan bahwa lama penyimpanan 0 jam hingga 3 jam tidak berbeda nyata, demikian pula dengan lama penyimpanan 6 hingga 12 jam. Namun selebihnya berbeda nyata pada penyimpanan 15 jam dan 18 jam.

Berdasarkan hasil penelitian menunjukkan terjadi penurunan nilai organoleptik tekstur seiring dengan lama penyimpanan. Pada lama penyimpanan hingga 12 jam tekstur masih memenuhi syarat, hal ini karena aktifitas mikroba yang terhambat oleh senyawa antibakteri yang 
terdapat dalam larutan ekstrak daun kelor. Denaturasi protein menyeabkan struktur berubah dan kemampuan mengikat air melemah, akibanya semakin lama penyimpanan hingga 18 jam terjadi penurunan mutu tekstur yang dipicu oleh adanya aktivitas enzim mikroba yang mengubah daging ikan menjadi lebih lunak.

\section{Nilai pH Ikan Layang (Decapterus sp.)}

Histogram nilai rata-rata $\mathrm{pH}$ ikan layang selama perendaman hingga 18 jam dapat dilihat pada Gambar 8.

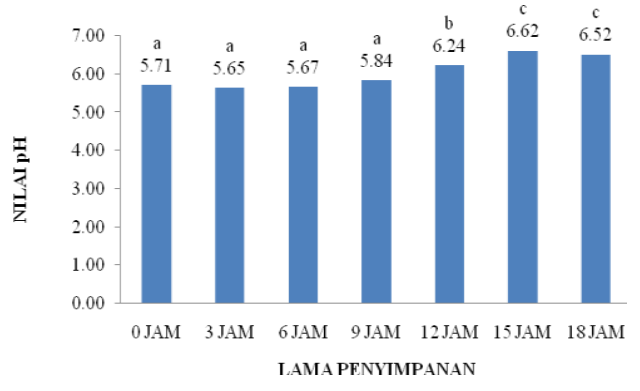

Gambar 8. Histogram nilai pH ikan layang pada lama penyimpanan yang berbeda.

Berdasarkan histogram pada Gambar 8, terjadi kenaikan jumlah $\mathrm{pH}$ pada lama penyimpanan yang berbeda. Hasil pengujian diperoleh bahwa nilai $\mathrm{pH}$ tertinggi pada sampel dengan lama penyimpanan 18 jam yaitu 6,52 , sedangkan terendah pada lama penyimpanan 3 jam sebanyak 5,65.

Batas maksimal pH pada ikan segar oleh badan standarisasi nasional tidak disyaratkan. Secara keseluruhan hasil pengujian nilai $\mathrm{pH}$ pada lama penyimpanan 0 jam - 18 jam masih memenuhi syarat sesuai dengan pernyataan
Junianto (2003) bahwa nilai pH ikan segar yakni berkisar 5.2 - 6.8 Sehingga pada lama penyimpanan sampai dengan 18 jam memenuhi syarat.

Berdasarkan uji Anova perlakuan lama penyimpanan yang berbeda berpengaruh nyata terhadap nilai pH yang dihasilkan. Hasil uji Duncan menunjukkan bahwa lama penyimpanan 0 jam, 3 jam, 6 jam dan 9 jam tidak berbeda nyata, tetapi berbeda nyata pada penyimpanan 12 jam, demikian pula dengan lama penyimpanan 15 jam dan 18 jam tidak berbeda nyata, tetapi berbeda nyata dengan penyimpanan 0 hingga 9 jam demikian pula dengan 12 jam.

Nilai $\mathrm{pH}$ erat pula kaitannya dengan tingkat pertumbuhan bakteri, semakin tinggi $\mathrm{pH}$ maka semakin tinggi pula kemampuan bakteri untuk melakukan pertumbuhan yang dapat menyebabkan menurunnya mutu ikan layang segar dan sebaliknya. Menurut Kasmadihardja (2008) nilai pH erat pula kaitannya dengan tingkat pertumbuhan bakteri, semakin rendah $\mathrm{pH}$ maka semakin rendah pula kemampuan bakteri untuk melakukan pertumbuhan yang dapat menyebabkan menurunnya nilai Total Plate Count (TPC). Jika dilihat dari hasil penelitian berasarkan nilai yang tertera pada histogram di atas, senyawa antibakteri yang terdapat pada daun kelor seperti flavonoid, saponin dan tannin memiliki efektifitas sebagai antimikroba, hal ini disebabkan oleh hasil pengujian pH tidak memilki jumlah kenaikan yang signifikan 
meskipun sampai pada lama penyimpanan 18 jam, semua kriteria penyimpanan, nilai yang diperoleh masi berada pada angka yang mendekati $\mathrm{pH}$ netral.

\section{SIMPULAN}

Berdasarkan hasil penelitian mengenai penggunaan larutan ekstrak daun kelor terhadap mutu ikan layang segar menunjukkan bahwa terdapat pengaruh yang signifikan terhadap karakteristik mutu hedonik (mata, insang, lendir, daging, tekstur, dan bau), mikrobiologi (TPC), dan $\mathrm{pH}$ selama penyimpanan 0 jam, 3 jam, 6 jam, 9 jam, 12 jam, 15 jam dan 18 jam. Penggunaan ekstrak daun kelor $75 \%$ mampu mempertahankan mutu ikan layang segar selama penyimpanan 12 jam dengan kriteria mata agak cerah, bola mata

\section{DAFTAR PUSTAKA}

Arizka, N. D. 2017. Kualitas dan Daya Simpan Ikan Kakap Merah dengan Daun Kelor Sebagai Pengawet Alami. Skripsi. Universitas Muhammadiyah Surakarta.

Ayotunde EO, F. O. (2011). toxicity of aqueous extract of Moringa oleifera seed powder to nile tilapia oreochromis niloticus (LINNE 1779), fingerlings. International Research Journal of Agricultural Science and Soil Science.

Badan Standar Nasional. 2006. SNI 01-2729.22006 tentang Ikan Segar Bagian 2: Persyaratan Mutu Bahan Baku. BSN. Jakarta. rata, pupil agak keabu-abuan, kornea agak keruh; insang warna merah agak kusam tanpa lendir; tekstur agak padat, agak elastis bila ditekan dengan jari, sulit menyobek daging dari tulang belakang; bau netral dan sayatan daging sedikit kurang cemerlang, spesifik jenis, tidak ada pemerahan sepanjang tulang belakang, dinding perut daging utuh.

Hasil uji kimia menunjukkan bahwa ikan layang segar yang direndam selama 30 menit dengan konsentrasi larutan daun kelor $75 \%$ yang disimpan selama 12 jam memiliki pH 6,24 dan secara mutu mikrobiologi diperoleh nilai TPC yaitu logaritma 5,63 CFU/gr, hal ini memenuhi syarat SNI 2729.2013 tentang mutu dan keamanan ikan segar yaitu $5 \times 10^{5}$.

Badan Standarisasi Nasional Indonesia. 2013. Ikan Segar SNI 2729-2013. Dewan Standarisasi Nasional Indonesia. Jakarta.

DKP Provinsi Gorontalo. 2014. Data Hasil Tangkapan Provinsi Gorontalo. Dinas Kelautan dan Perikanan. Gorontalo.

Hizaz, A. J. 2011. Perbedaan Hanging Ratio Jaring Rampus Terhadap Hasil tangkapan Ikan Layang (Decapterus Kurroides) di Perairan Cisolok, Pelabuhan ratu. [Skripsi]. Bogor: Fakultas Perikanan dan IImu Kelautan, Institut Pertanian Bogor.

Ibrahim, B. S. F. 2017. Karakteristik Mutu Ikan Nila (Oreochromis niloticus) Segar Pada Larutan Kemangi (Ocimum basillicum L.) Dengan Lama Perendaman Yang Berbeda. [Skripsi]. Fakultas Perikanan dan Ilmu Kelautan. Universitas Negeri Gorontalo. Gorontalo 
Mapiliandari, I., dkk. 2008. Aktivitas Antimikroba dari Oleoresin Tanaman Rempah. Akademi kimia Analis. Jurnal Warta Akab. 19:1-11.

Moeljanto. 1992. Pengawetan dan pengolahan Hasil Perikanan. Penebar Swadaya. Jakarta.

Murniyati, A.S., Sunarman. 2000. Pendinginan, Pembekuan dan Pengawetan Ikan. Penerbit Kanisius. Yogyakarta.

Ruchmana, A. S., Indra 2017. Pengaruh Waktu Penyimpanan Larutan Oral Nutraceutical Ekstrak Bunga Delima Merah (Punica granatum L.) Terhadap Perubahan Hambatan Pertumbuhan Bacillus subtilis (In Vitro) . [Skripsi]. Surakarta: Fakultas Kedokteran Gigi Universitas Muhammadiyah.

Sulistyo, J., Soeka, Y.S. 1999 Bioproses enzimatik dan uji hayati aktifitas polifenol glikosida sebagai senyawa antimikroba. Dalam: Kosela dan WP Suwarsono (Penyunting). Kimia bahan Alam. Prosiding Seminar Nasional. UI-UNESCO, Jakarta.

Widowati, I. D. 2014. Uji Aktivitas Ekstrak Daun Kelor (Moringa oleifera) Terhadap Bekteri Pembusuk. Jurnal PELITA. 9(1). 